\title{
Ecosystems, Pollution, and Use of Resources in Textbooks of 14 Countries: An Ecocentric Emphasis
}

\author{
Rosa Branca Tracana ${ }^{1}$ and Graça S. Carvalho \\ ${ }^{1}$ High School of Education, Communication and Sport, Polytechnic Institute of Guarda, Guarda, Portugal \\ ${ }^{2}$ CIEC, Institute of Education, University of Minho, Braga, Portugal
}

Correspondence should be addressed to Rosa Branca Tracana, rb.tracana@gmail.com

Received 8 December 2011; Accepted 2 January 2012

Academic Editors: F. Jimenez and B. J. Walton Moss

Copyright ( $) 2012$ R. B. Tracana and G. S. Carvalho. This is an open access article distributed under the Creative Commons Attribution License, which permits unrestricted use, distribution, and reproduction in any medium, provided the original work is properly cited.

\begin{abstract}
Two views of Human-Nature relation can be found: anthropocentrism and ecocentrism. In order to understand how school textbooks refer to the human's position in nature we analysed how "Human as guest versus Humans as owners of nature" is present in the three topics of environmental education-Ecosystems, Pollution, and Use of Resource-in textbooks of 14 countries from Europe, Africa, and Middle East. A specific grid of analysis, which was constructed in the context of the European Project BIOHEAD-CITIZEN, was used in this study. Results show that this axis of analysis is present in the majority of textbooks addressing the above three topics but not in the "Biodiversity" topic. Textbooks for 12-15-year old pupils were the ones having more occurrences than those for 6-11- or 16-18-year olds. The textbooks present mainly an ecocentric position, whereas the aesthetic, ethical, and cultural aspects are limited and inadequate, limiting the full perspective of education for sustainable development.
\end{abstract}

\section{Introduction}

The understanding of the Human-Nature relationship affects strongly people's worldviews [1], and differences in worldviews determine the way people conceptualize the need for addressing solutions of the existing environmental problems. As Esteves [2] defends it is necessary to develop, in each of us and also in the humanity, the sense of responsibility and solidarity through the environment.

Two perspectives of Human-Nature relation can be found: anthropocentrism and ecocentrism [3]. The former focuses in the relations between humans and the Universe [2] and confers humans' dominance over nature, where they, in the ecosystem, occupy the top of an alimentary chain. The latter aims at the ecosystem itself, where the humans are seen as elements of the biotic community, having an attitude of respect for all the elements of that community [3]. It is simple to understand that these questions are not easy to solve but one has to have in mind ethical positions in order to solve the different environmental problems. It is also required a moral, ecological, and economic perspective in the relation Human-Nature. This is to say that there is a need for a change of attitudes in order to obtain a better world. In the sense of changing attitudes through the environment, in the sense of constructing a better world, it is pertinent the intervention of educative actions to make children and young people aware of environmental problems and promote positive attitudes and behaviours.

Textbooks analysis is seen as a major element in the evaluation of how the educational goals (at the legislative level of national programmes) are implemented at the school level, where pupils must acquire knowledge, competences and develop appropriate values towards a sustainable environment [4]. These textbooks are used by teachers with a double function: as a national programme (or syllabuses) guideline and as a didactical resource [5]. Thus the textbook analysis turns out to be a relevant tool for studying socio-cultural determinants of environmental problems, in particular the schoolrelated ones.

In order to understand how school textbooks refer to the human's position in nature we analysed how the axis "Human as guest versus Humans as owners of nature" is present in three topics of environmental education-Ecosystems, Pollution, and Use of Resource - in textbooks of 14 countries 
Table 1: Part of the Pollution grid related to Human as guest versus Humans as owners of nature.

\begin{tabular}{|c|c|c|c|c|}
\hline $\begin{array}{l}\text { Content } \\
\text { (Themes, topics) }\end{array}$ & Indicators & $\begin{array}{l}\text { Page number } \\
\text { of images }\end{array}$ & $\begin{array}{l}\text { Figure number } \\
\text { of images }\end{array}$ & $\begin{array}{c}\text { Occurrences } \\
\text { in text }\end{array}$ \\
\hline \multirow{6}{*}{$\begin{array}{l}\text { Impacts of } \\
\text { pollution }\end{array}$} & Impact on humankind (only benefits and risks for humans) & & & \\
\hline & Economic consequences & & & \\
\hline & Social risks & & & \\
\hline & Aesthetic values & & & \\
\hline & Ethic, moral, and cultural motivations (e.g., future generations) & & & \\
\hline & Impact to ecosystem & & & \\
\hline
\end{tabular}

TABLE 2: Part of the Use of Resources grid related to Human as guest versus Humans as owners of nature.

\begin{tabular}{|c|c|c|c|c|}
\hline $\begin{array}{l}\text { Content } \\
\text { (themes, topics) }\end{array}$ & Indicators & $\begin{array}{l}\text { Page number } \\
\text { of images }\end{array}$ & $\begin{array}{c}\text { Figure number } \\
\text { of images }\end{array}$ & $\begin{array}{c}\text { Occurrences } \\
\text { in text }\end{array}$ \\
\hline \multirow{3}{*}{ Resource availability } & Finite (limited) availability of resources & & & \\
\hline & Infinite (unlimited) availability of resources & & & \\
\hline & Renewable or nonrenewable resources, including food & & & \\
\hline \multirow{4}{*}{ Sustainability } & Ecological sustainability & & & \\
\hline & Social sustainability & & & \\
\hline & Economic sustainability & & & \\
\hline & Ecological-social-economic sustainability & & & \\
\hline \multirow{9}{*}{ Equity } & Resources distribution & & & \\
\hline & Differences in distribution & & & \\
\hline & Relevant factors for equity of distribution & & & \\
\hline & Ecological conditions & & & \\
\hline & Cultural conditions (knowledge, technology, education,...) & & & \\
\hline & Ethical, moral norms & & & \\
\hline & Economic conditions & & & \\
\hline & Political decisions & & & \\
\hline & International agreements & & & \\
\hline
\end{tabular}

from Europe, Africa, and Middle East, having geographic, socioeconomic, and cultural differences.

\section{Methodology}

This work was performed by using specific parts of the grid of textbook analysis on the topic "Ecology and Environmental Education" constructed by the European FP6 STREP project BIOHEAD-CITIZEN (CIT2-CT-2004-506015) [6, 7]. For the design of the grids of textbooks analysis, precise subtopics being exemplar of interactions between science and society, and challenges in Citizenship were chosen. They were Pollution, Use of Resources, Ecosystem, and Cycles and Biodiversity.

The corpus of the present study was composed of 128 textbooks containing the topic Ecosystems and Cycles, Pollution and the Use of Resources in 14 countries involved in the European project FP6 BIOHEAD-CITIZEN CIT2CT-2004-506015 [8]: Cyprus, Estonia, Finland, France, Germany, Hungary, Italy, Lebanon, Lithuania, Malta, Morocco, Portugal, Romania, and Senegal.

The previous three topics were analysed in each country textbook by the respective project teams by looking specifically to the axis "Human as guest versus Humans as owners of nature" [9]. The textbooks analysed were the ones more used in each country, and in some countries only one textbook was used in schools. We looked for images and textual occurrences by using the grids of analysis. For each indicator we registered the images occurrences that appeared in the textbooks (Tables 1, 2, and 3). The problem of subjective interpretation in this kind of qualitative analyse was controlled by having two analysts separately applying the grids and cross-checking the findings afterwards.

A qualitative approach was used for textbooks analysis but quantitative analysis was also used wherever possible in order to be able to compare items among countries.

\section{Results and Discussion}

The analysis of the textbooks showed that the axis "Humans as owners versus Humans as guests of nature" appears in three subtopics of environmental education: Pollution, Use of Resources, and Ecosystems and Cycles, but not in Biodiversity. This absence can be due to the fact that this axis in Biodiversity is not considered so important. In other studies [9] it was also found that little importance was given to Biodiversity in all textbooks as compared to the topic Pollution or the Use of 
TABLe 3: Part of the Ecosystems and Cycles grid related to Human as guest versus Humans as owners of nature.

\begin{tabular}{llc}
\hline $\begin{array}{l}\text { Content } \\
\text { (themes, topics) }\end{array}$ & Indicators & $\begin{array}{c}\text { Page number } \\
\text { of images }\end{array}$ \\
\hline & $\begin{array}{c}\text { Figure number } \\
\text { of images }\end{array}$ & $\begin{array}{c}\text { Occurrences } \\
\text { in text }\end{array}$ \\
Motivation for conservation (only if explicitly mentioned in the text) & \\
and management & To preserve a source of aesthetic pleasure for humans \\
of nature & To prevent exhaustion of natural resources important for economy \\
& To prevent ecological disequilibrium \\
& To respect nature and all living beings \\
\hline
\end{tabular}

TABLe 4: Textual occurrences of the Human as guest versus Humans as owners of nature in the subtopic Pollution in 40 textbooks.

\begin{tabular}{|c|c|c|c|c|}
\hline \multirow{2}{*}{ Textual occurrences } & \multicolumn{3}{|c|}{ Pupils' age } & \multirow{2}{*}{ Tota } \\
\hline & $6-11$ & $12-15$ & $16-18$ & \\
\hline Impact on humankind & 21 & 39 & 31 & 91 \\
\hline Economic consequences & 4 & 6 & 14 & 24 \\
\hline Social risks & 2 & 14 & 5 & 21 \\
\hline Aesthetic values & 2 & 2 & 5 & 9 \\
\hline Ethic, moral, and cultural motivations & 0 & 7 & 2 & 9 \\
\hline Impact to ecosystems & 51 & 72 & 67 & 190 \\
\hline Total & 80 & 140 & 124 & 325 \\
\hline
\end{tabular}

Resources. It seems that textbooks refer to the problematic of species extension but not in a deep manner. This is a curious aspect because today the media address constantly these problems and the school should also take these matters into account in order to contribute for a better citizenship.

This axis "Humans as owners versus Humans as guests of nature" is present in the majority of textbooks. Those books for 12-15-year-old pupils are the ones having more occurrences than those for 6-11- or 16-18-year old, in all the three subtopics Pollution, Use of Resources and Ecosystem and Cycles as it can be observed in Tables 4, 5, and 6 .

As regards the analysis of the "Human owners of nature versus Humans as guests," the textbooks were analysed in order to understand how humans are seen in their environment. The impact of pollution was analyzed at several levels, from the aesthetic to the impact on humanity.

In Table 4 it can be seen that the item "Impact to ecosystems" is the most referred one, followed by the "Impact on humankind." This occurs, perhaps, because they are the ones that have more impact in human life. The "Aesthetic values" and "Ethic, moral and cultural motivations" have residual presence, which means that the textbooks do not give importance to these issues.

The aesthetic values are beauty values [10], and our results showed that they are poorly referred. Not only aesthetic but also ethic and cultural issues were found to be absent in the axis of Human as guest versus Humans as owners of nature, indicating that textbooks are not approaching appropriately the sustainability aim. This is a point which should be improved in the textbooks. According to Sachs [11], to reach environmental sustainability it is necessary to consider simultaneously (i) social aspects, with the goal of reducing distance between life pattern of social groups; (ii) economical aspects, made possible by an efficient allocation and management of the resources, much more under macros social criteria than micros social entrepreneurs and by regular flow of public and private investment; (iii) ecological aspects, involving measures to reduce the resources consumption, and residual production, measures to intensify research, to introduce clean and resource saving technologies, and to define rules that allow an appropriated environmental protection; (iv) spatial aspects, looking into a more balanced configuration of the rural-urban issue; (v) cultural aspects, in order to get endogenous conceptions of involvement that respect the peculiarity of each ecosystem, each culture and each place.

It was intended to understand whether the textbooks advocate that humans are seen in an anthropocentric perspective where they dominate the environment or, on the contrary, humans are seen as part of the environment and they cannot use it just for their own desire.

In Table 5 we can observe that Renewable or nonrenewable resources are more referred (42 occurrences) in the textbooks than the other items. This demonstrates that the textbooks are preoccupied to pass the information to pupils that the natural resources are not infinite, and they should be economically and rationally used. Torres [12] claims that it is important to understand that humanity must not dominate nature but interact with it. This is to say that nature should be taken to attend not only the needs of the present generation but also those of the subsequent generations. This leads to the importance of environmental education for the sustainable development.

For the analysis of humans in nature position as far as resource availability and sustainability are concerned, the analysed textbooks tend to transmit mainly an ecocentric position. However when looking at equity, the economic 
TABLE 5: Textual occurrences of the Human as guest versus Humans as owners of nature in the subtopic Use of Resources in 31 textbooks.

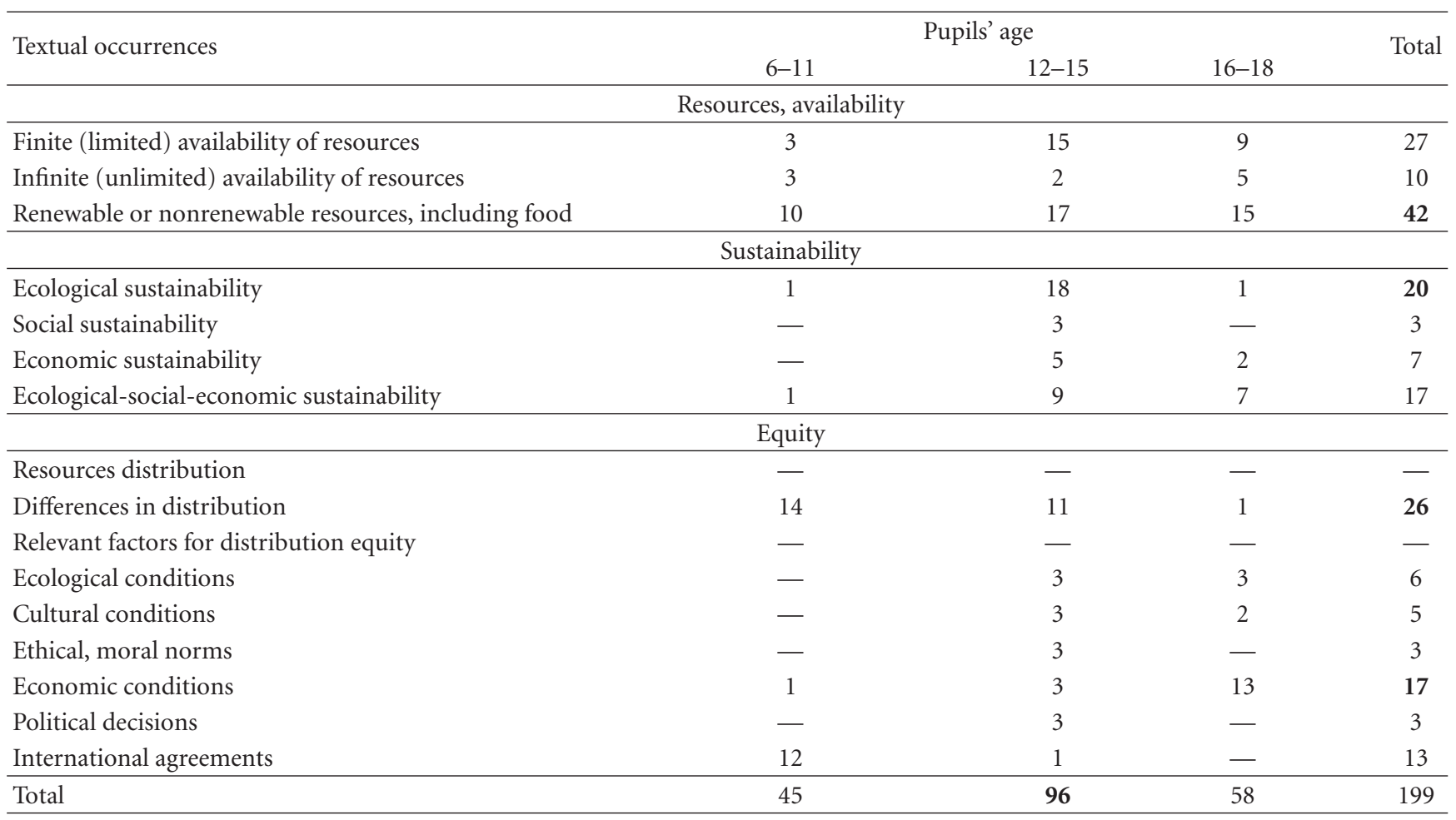

TABLE 6: Textual occurrences of the Human as guest versus Humans as owners of nature in the subtopic Ecosystems in 28 textbooks.

\begin{tabular}{|c|c|c|c|c|}
\hline \multirow{2}{*}{ Textual occurrences } & \multicolumn{3}{|c|}{ Pupils' age } & \multirow{2}{*}{ Total } \\
\hline & $6-11$ & $12-15$ & $16-18$ & \\
\hline To preserve a source of aesthetic pleasure for humans & 4 & 7 & 2 & 13 \\
\hline To prevent exhaustion of natural resources important for economy & 1 & 12 & 3 & 16 \\
\hline To prevent ecological disequilibrium & 2 & 21 & 2 & 25 \\
\hline To respect nature and all living beings & 35 & 9 & 3 & 47 \\
\hline Total & 42 & 49 & 10 & 101 \\
\hline
\end{tabular}

conditions are the most referred item, suggesting the societal importance given to economy in the goods distribution.

In the case of the subtopic Ecosystems we observed that the respect of nature and living beings was the item more referred to. Once again the aesthetic aspect is the less considered. These results show that the analysed textbooks consider "men as invited" and not as "owner of nature." Given the problematic of ecosystems, these textbooks advocate an ecocentric position. They intend to pass the information that people must preserve the nature as it is, but unfortunately they do not convey what measures people must take to ensure that it is not destroyed.

In conclusion, we can say that the textbooks from 14 countries tend to defend the ecocentric perspective, where humans are seen as guest of nature and not its owner. Results also show that, in respect to this axis "Humans as owner's versus Humans as guests of nature" the aesthetic, ethical, and cultural aspects are inadequate, limiting the education for sustainable development. To reach the sustainability, it is necessary to look the social, economic, ecological, spatial, and cultural aspects all together $[11,13]$.

Comparison of results obtained from the seventeen countries, textbooks of our study, made it possible to identify the relevant challenges facing our education system-and to various countries - and thus contributes to improving these emerging aspects, to strengthen a society based on environmental literacy and citizenship [9].

With this comparative study among several countries textbooks, it was intended to know not only how these topics are covered for the contents but also how the attitudes and behavior towards the environment are presented. The aim is to formulate proposals to improve textbooks so that they contribute better to the promotion of students' positive attitudes and skills towards the recognition of the importance of the environment and its sustainability.

Further studies are going on to find out whether textbooks from groups of countries (Western or Eastern European countries and non-European countries-African and 
Middle East countries) show specific tendencies in the way environmental education deals with the issue "Humans as owner's versus Humans as guests of nature."

\section{Acknowledgments}

This work had the financial support of the European project FP6 Biohead-Citizen CIT2-CT-2004-506015, the Portuguese FCT project ("Analysis of School Textbooks" PTDC/CED/ 65224/200), and the research centre CIEC (FCT unit 317). The authors particularly thank the colleagues who gathered data or coordinated this process concerning the topic "Health Education" in the textbooks of their respective countries: Nicos Valanides (Cyprus), Kai Pata and Tago Saraparuu (Estonia), Anna-Liisa Kosonen (Finland), Dominique Berger and Pierre Clément (Lyon, France), Claude Caussidier and Daniel Favre (Montpellier, France), Christine Geier and Franz Bogner (Germany), Dániel Horváth and Attila Varga (Hungary), Adriana Valente, Luzi Daniela and Silvia Caravita (Italy), EL-Hage Fadi, Odile Saab and Iman Khalil (Lebanon), Grita Skujiene and Jurga Turcinaviciene (Lithuania), Desireè Scicluna Bugeja and Paul Pace (Malta), Sabah Selmaoui (Morocco), Adrienne Kozan (Romania), Mame Seyni Thiaw, and Valdiodio Ndiaye (Senegal).

\section{References}

[1] C. Rehmann-Sutter, "Biological organicism and the ethics of the human-nature relationship," Theory in Biosciences, vol. 119, no. 3-4, pp. 334-354, 2000.

[2] L. M. Esteves, Da Teoria à Prática: Educação Ambiental com as Crianças Pequenas ou o Fio da História, Porto Editora, Lisbon, Portugal, 1998.

[3] A. Almeida, Educação Ambiental A Importância da Dimensão, Livros Horizonte, 2007.

[4] ME-Ministério da Educação, Manuais Escolares-Análise da Situação, Edição do, Lisbon, Portugal, 1988.

[5] G. S. Carvalho, D. Jourdan, A. Gonçalves, C. Dantas, and D. Berger, "Addictive substances: textbook approaches from 16 countries," Journal of Biological Education, vol. 44, no. 1, pp. 26-30, 2009.

[6] G. S. Carvalho and P. Clément, "Projecto "Educação em Biologia, educação para a saúde e Educação ambiental para uma melhor cidadania": análise de manuais escolares e concepções de professores de 19 países (europeus, africanos e do próximo oriente)," Revista Brasileira de Pesquisa em Educação em Ciências, vol. 7, no. 2, pp. 1-21, 2007.

[7] S. Caravita, G. Berthou, P. Pace et al., "Design and construction of the EEE grids," Science Education International, vol. 19, no. 2, pp. 97-116, 2008.

[8] G. S. Carvalho, "Biology, Health and Environmental Education for better Citizenship," STREP CIT2-CT-2004-506015, European Commission, Brussels, FP6, 2004, http://projectos .iec.uminho.pt/projeuropa/.

[9] R. B. Tracana, Educação ambiental no ensino básico e secundário: concepções de professores e análise de manuais escolares, Ph.D. thesis, Universidade do Minho, Braga, Portugal, 2009.

[10] E. Jeronen and M. Kaikkonen, "Thoughts of children and adults about the environment and environmental education,"
International Research in Geographical and Environmental Education, vol. 11, no. 4, pp. 342-353, 2002.

[11] I. Sachs, Estratégias de Transição Para o Século XXI: Desenvolvimento e Meio-Ambiente, Nobel/Fundap, Sao Paulo, Brazil, 1993.

[12] M. B. R. Torres, "A interface entre educação ambiental e gestão ambiental numa perspectiva das ciências sociais," Revista Electrónica Mestrado de Educação Ambiental, vol. 18, pp. 501512, 2007.

[13] I. Sachs, Desenvolvimento Includente, Sustentável Sustentado, Editora Garamond Lda, Rio de Janeiro, Brazil, 2004. 

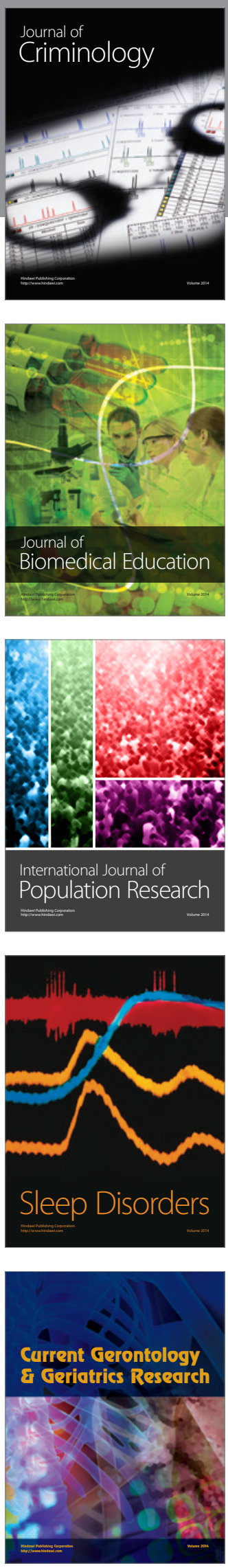
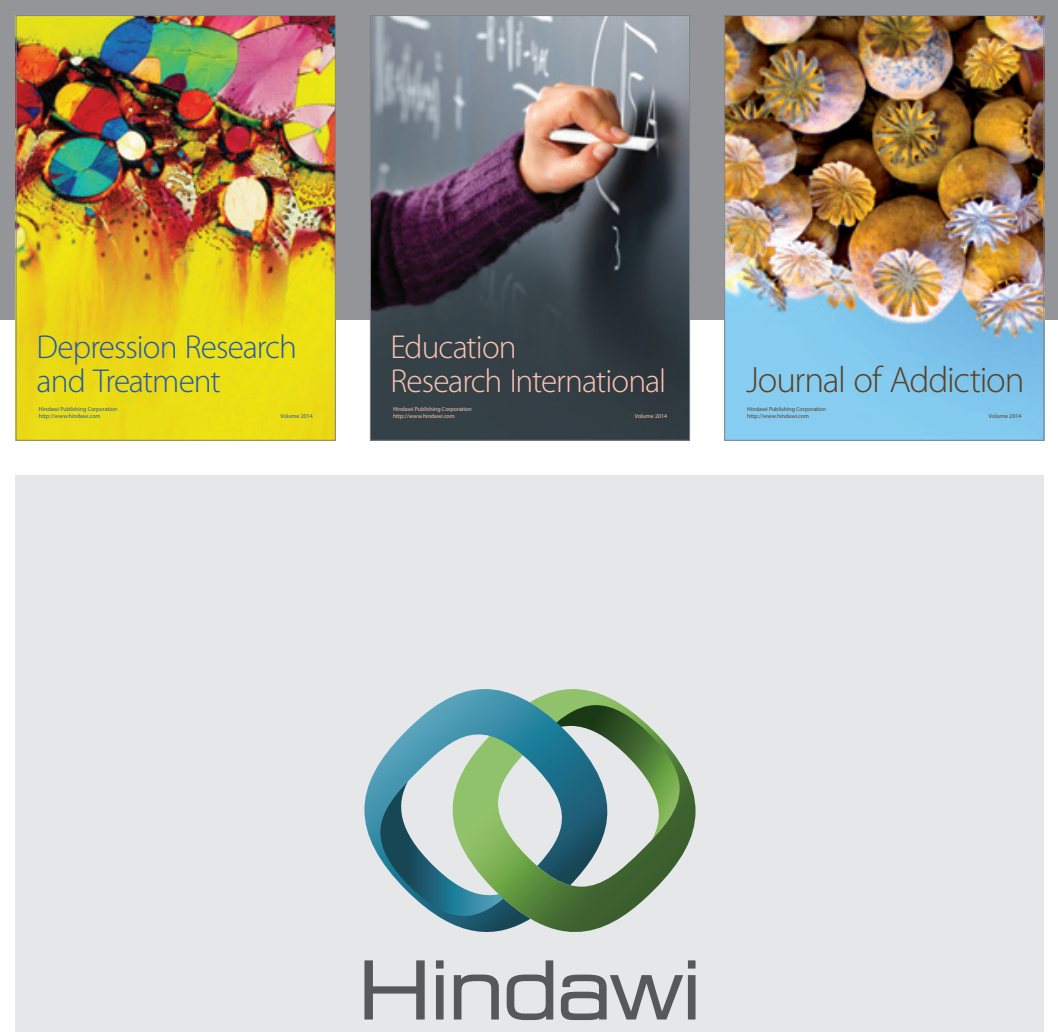

Submit your manuscripts at

http://www.hindawi.com

Child Development Research
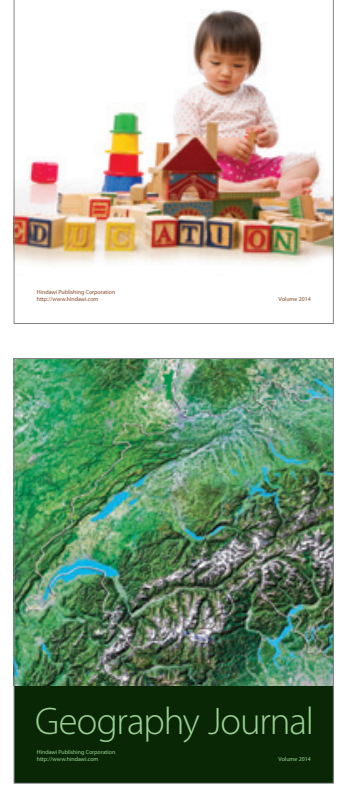

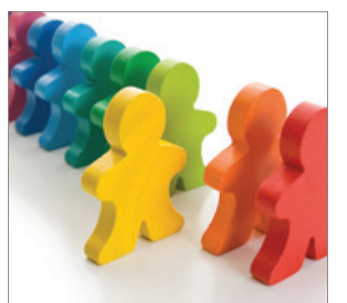

Autism

Research and Treatment
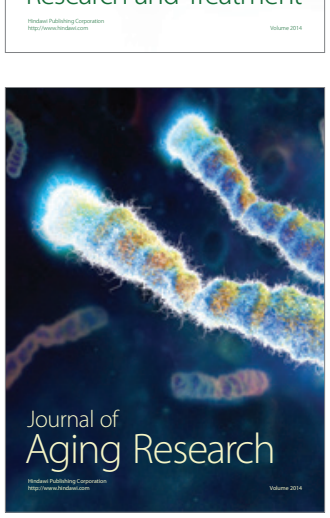
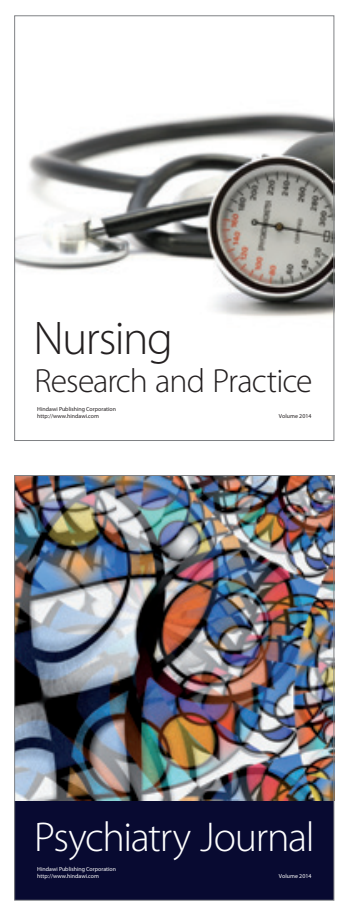
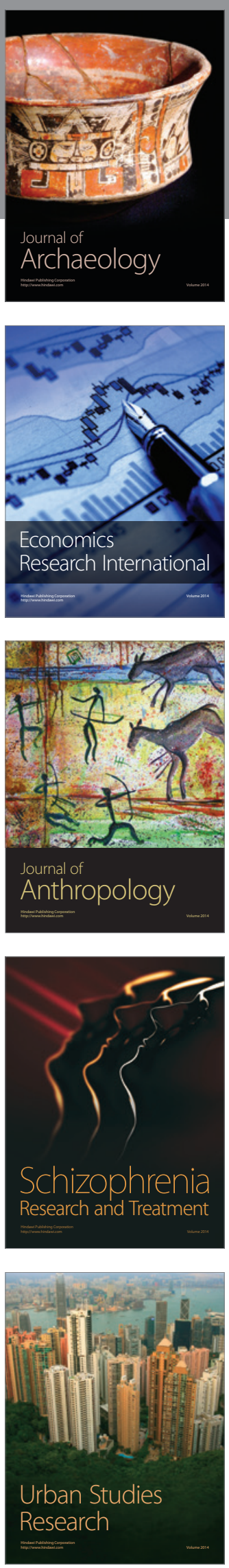